\title{
Stimulatory Effects of Monoacetyldiglycerides on Hematopoiesis
}

\author{
Hyun Ok YAnG, ${ }^{a}$ Jung-Sun PARK, ${ }^{b}$ So-Hye CHO, ${ }^{c}$ Jin-Young Yoon, ${ }^{c}$ Mi-Geum KIM, ${ }^{c}$ Gil-Ja JHon, ${ }^{c}$ \\ So-Yeop HaN, ${ }^{c}$ and Sang Hee $\mathrm{KIM}^{*}, b$ \\ ${ }^{a}$ Department of Anesthesiology \& Pain Management, Asan Institute for Life Sciences, College of Medicine, University of \\ Ulsan; 388-1 Poongnap-dong, Songpa-ku, Seoul 138-736, Korea: ${ }^{b}$ Division of Hemato-Oncology, Asan Institute for Life \\ Sciences, College of Medicine, University of Ulsan; 388-1 Poongnap-dong, Songpa-ku, Seoul 138-736, Korea: and \\ ${ }^{c}$ Department of Chemistry and Division of Molecular Life Sciences, Ewha Womans University; 11-1 Daehyun-dong, \\ Seodaemun-ku, Seoul 120-750, Korea. Received March 11, 2004; accepted April 21, 2004
}

\begin{abstract}
Monoacetyldiglycerides purified from deer antler, and identical synthetic compounds, have been shown to stimulate hematopoiesis. In the present study, we synthesized eight monoacetyldiglycerides, one of which, 1palmitoyl-2-linoleoyl-3-acetyl-rac-glycerol (3), was structurally identical to one of the naturally occurring monoacetyldiglycerides and showed the most potent stimulation of hematopoiesis by colony forming unit in culture (CFUc) assay, having a stimulation index (SI) of $1.54 \pm 0.23$ at a concentration of $1.0 \mu \mathrm{g} / \mathrm{ml}$. Moreover, $1.0 \mu \mathrm{g} / \mathrm{ml} 3$ showed potent growth-stimulation activities on megakaryocyte culture, long term culture of Lin ${ }^{-} \mathrm{Sca}-$ $1^{+}$cells with irradiated MS-5 stromal cells (SI, 1.69 \pm 0.16 ), and on the number of cobblestone colonies (SI, 10.4 \pm 0.25 ). In a murine model, 3 , at concentrations of $0.5,5$ and $50 \mathrm{mg} / \mathrm{kg} / \mathrm{d}$, i.p. and p.o., effectively stimulated hematopoiesis in vivo $7 \mathrm{~d}$ after syngenic bone marrow transplantation of irradiated C57BL/6 mice, when assayed by the colony forming units in spleen (CFUs) assay. These data suggest that monoacetyldiglycerides may have significant clinical potential for the acceleration of hematopoiesis.
\end{abstract}

key words Cervus nippon; monoacetyldiglyceride; hematopoesis; synthetic monoacetyldiglyceride

In traditional Oriental medicine, extracts from the antler of the deer, Cervus nippon TEMmenick (Cervidae), have been used to treat a variety of ailments for over thousands years. Traditionally, water extracts of deer antler were used as "tonics" for patients with anemia, anorexia, and fatigue. ${ }^{1-3)}$ More recently, deer antler extract was observed to accelerate recovery from hematopoietic injuries induced by cancer chemotherapy and/or radiation therapy. ${ }^{4,5)}$ We previously reported that monoacetyldiglycerides purified from deer antler were the active hematopoiesis stimulating components of this traditional medicine. ${ }^{6}$ We also showed that four of these monoacetyldiglycerides, synthesized de novo from glycerol and appropriate fatty acids, possessed similar activities. ${ }^{7)}$

In the present study, we have expanded our examination of the biological activities of deer antler-derived monoacetyldiglycerides by synthesizing eight of these compounds and studying their ability to stimulate hematopoietic stem cells in vitro.

Here we report that one of these synthetic compounds, 1-palmitoyl-2-linoleoyl-3-acetyl-rac-glycerol (3), which is structurally identical to one of the naturally occurring monoacetyldiglycerides, showed the most potent stimulation of hematopoiesis in vitro and in vivo. To determine its mode of action, we studied the effects of $\mathbf{3}$ on hematopoietic stem cells and bone marrow stromal cells in vitro.

\section{MATERIALS AND METHODS}

Instruments and General Methods All solvents were the highest grade commercially available and distilled prior to use. Aqueous solutions were prepared using deionized and distilled water. High performance thin layer chromatography (HPTLC) and silica gel column chromatography were performed using Merck Kieselgel $60 \mathrm{~F}_{254}$ and Kieselgel 60, 230 - 400 mesh ASTMC silica gels, respectively. Cervus nippon antler was purchased at Kyungdong Traditional Med- icine Market, and its authenticity was certified by the Natural Products Research Institute, Seoul National University. NMR analyses were conducted at $250 \mathrm{MHz}$ for ${ }^{1} \mathrm{H},{ }^{1} \mathrm{H}-{ }^{1} \mathrm{H}$ COSY NMR, $63 \mathrm{MHz}$ for DEPT $135,{ }^{13} \mathrm{C}-\mathrm{NMR}$, and $500 \mathrm{MHz}$ for HMQC NMR in $\mathrm{CHCl}_{3}$ with tetramethylsilane (TMS) as an internal standard. Positive FAB mass spectra were recorded with a JMS-HX 110/110A four-sector tandem mass spectrometer (JEOL, Tokyo, Japan).

Animals $\mathrm{C} 57 \mathrm{BL} / 6$ and $\mathrm{C} 3 \mathrm{H}$ male mice, 6-8 weeks old, were used in all experiments. The animals were housed in specific pathogen free (SPF) environmental conditions (temperature, $22 \pm 2{ }^{\circ} \mathrm{C}$; humidity, $60 \pm 4 \%$ ) with a $12 \mathrm{~h}$ light/dark cycle at the Animal House of the Asan Institute for Life Sciences, University of Ulsan. Water was provided ad libitum.

Purification and Structural Identification of Deer Antler Monoacetyldiglycerides Monoacetyldiglycerides were purified and their structure was determined as previously described. ${ }^{6}$ Briefly, $1.5 \mathrm{~kg}$ of the crude powder of Cervus nippon antler was refluxed with 51 hexane, and the residue was dried absolutely and refluxed with $51 \mathrm{CHCl}_{3}$. Biologically active compounds were purified from the chloroform extract by repeated silica gel chromatography, and they were identified as monoacetyldiglycerides by mass spectrometry, NMR and IR.

Synthesis of Monoacetyldiglycerides Eight monoacetyldiglycerides were synthesized from glycerol and appropriate fatty acids, and their structure was confirmed by spectroscopic methods, as described. ${ }^{7)}$ All reactions were carefully conducted and closely monitored by thin-layer chromatography (TLC) in order to obtain the target monoacetyldiglycerides with high regioselectivity. Purity of all intermediates and the target molecule was verified by ${ }^{1} \mathrm{H}-$, ${ }^{13} \mathrm{C}$-, and 2D COSY NMR, IR and high-resolution FAB mass measurements.

Colony Forming Unit in Culture (CFUc) Assay Bone marrow cells were obtained by flushing femurs and tibias of 
mice, and single cell suspensions were obtained by repeated aspiration. Suspensions of bone marrow cells were passed through a Sephadex G-10 column to remove adherent cells, including macrophages and stromal cells. The bone marrow cells were further purified by discontinuous percoll gradient centrifugation $(1.063<\rho<1.075)$ to obtain a stem cell rich fraction of low density (LD) cells. LD cells $\left(3 \times 10^{5} / 35 \mathrm{~mm}\right.$ Petri dish) were cultured in medium containing $1.1 \%$ methylcellulose, 20\% fetal bovine serum (FBS), and 1\% penicillinstreptomycin. Monoacetyldiglycerides dissolved in $0.1 \%$ ethanol were added to the dishes at concentrations of 0.1 and $1 \mu \mathrm{g} / \mathrm{ml}$, and the cells were cultured for 1 week at $37^{\circ} \mathrm{C}$ in a $5 \% \mathrm{CO}_{2}$ incubator. The number of colonies was counted under an inverted microscope and compared with control dishes. Colony forming efficiency was expressed as stimulation index (SI) according to the equation,

$$
\mathrm{SI}=\frac{\text { total no. of colonies in sample group }}{\text { total no. of colonies in control group }}
$$

The LD cells were treated with a mixture of mAbs against CD4, CD8, Mac-1, Gr-1, and TER119, followed by extraction with anti-biotin micro-magnetic beads (MACS beads, Miltenvi Biotec, Bergich Gladbach, Germany) to deplete cells of the myeloid/lymphoid lineage. Lin $^{-}$cells were labeled with anti-Sca-1 micro-magnetic beads to isolate Sca$1^{+}$cells using a MACS column (Miltenvi). Lin $^{-} \mathrm{Sca}-1^{+}$cells were plated at $1.2 \times 10^{4}$ cells $/$ dish in $35-\mathrm{mm}^{2}$ tissue culture dishes and grown for $14 \mathrm{~d}$ at $37^{\circ} \mathrm{C}$ in a $5 \% \mathrm{CO}_{2}$ incubator in Iscove's modified Dulbecco's medium (IMDM, GIBCO, Grand Island, NY, U.S.A.) supplemented with 10\% FBS (GIBCO), 10\% abdominal wall-conditioned medium, and $1.1 \%$ methylcellulose, with or without 0.1 or $1 \mu \mathrm{g} / \mathrm{ml}$ purified monoacetyldiglycerides from deer antler or synthetic compound 3.

Long Term Culture of Lin $^{-}$Sca- ${ }^{+}$Cells with Stromal Cells Exposed to Compound 3 MS-5 cells, a mouse stromal cell line derived from $\mathrm{C} 3 \mathrm{H}$ bone marrow cells, ${ }^{8)}$ were irradiated at 20 Gy with a cesium ${ }^{137}$ irradiator. The MS-5 cells were exposed to 3 at concentrations of $0.01,0.1$ and $1 \mu \mathrm{g} / \mathrm{ml}$ or to $0.1 \%$ ethanol-medium solution (negative control) for $24 \mathrm{~h}$ after irradiation. Cells were cultured in $\alpha$-MEM supplemented with $12.5 \%$ FBS, $12.5 \%$ horse serum (Gibco) and $10^{-6} \mathrm{M} / 1$ hydrocortisone, washed with medium, and co-cultured for 6 weeks with $\mathrm{Lin}^{-} \mathrm{Sca}-1^{+}$cells $\left(1 \times 10^{3}\right.$ per $25 \mathrm{~cm}^{2}$ flask), replacing the medium every week. The number of cobble stone colonies per flask was counted. ${ }^{9,10)}$

Expression of SDF-1 mRNA in MS-5 Cells by RealTime $\mathrm{SyBr}^{\circledR}$ Green PCR Quantitative RT-PCR was performed on RNA derived from MS-5 cells pretreated with 3 and from untreated cells. Real-time PCR SyBr Green PCR systems for mouse glyceraldehyde-3-phosphate dehydrogenase (GAPDH) and SDF-1 were run in separate wells. The PCR reactions contained $50 \mathrm{~nm}$ of each primer and PCR Mastermix (SyBr Green Universal PCR Mastermix, Applied Biosystems), containing $10 \mathrm{~mm}$ Tris- $\mathrm{HCl}$ (pH 8.3), $50 \mathrm{~mm}$ $\mathrm{KCl}, 5 \mathrm{~mm} \mathrm{MgCl}_{2}, 2.5 \mathrm{~mm}$ deoxynucleotide triphosphates, 0.625 AmpliTaq Gold DNA polymerase, 0.25 U AmpErase $\mathrm{UNG}$, and $5 \mu \mathrm{l}$ of the diluted cDNA sample in a final volume of $25 \mu \mathrm{l}$. The samples were placed in 96-well plates and amplified in an automated fluorometer (ABI Prism $7700 \mathrm{Se}-$ quence Detection System, Applied Biosystems). The amplifi- cation conditions were $2 \mathrm{~min}$ at $50^{\circ} \mathrm{C}$ and $10 \mathrm{~min}$ at $95^{\circ} \mathrm{C}$, followed by 40 cycles of $30 \mathrm{~s}$ at $94^{\circ} \mathrm{C}, 30 \mathrm{~s}$ at $56^{\circ} \mathrm{C}$ and $50 \mathrm{~s}$ at $72^{\circ} \mathrm{C}$. Quantitation was achieved by the standard curve method, and results are reported as the n-fold difference relative to a calibrator cDNA. Primers for SDF-1 were $5^{\prime}$-GCA TCA GTG AGG GTA AAC CAG T-3' (sense) and 5'-CCA GGT ACT CTT GGA TCC ACT T -3' (antisense).

Megakaryocyte Culture Livers were removed from the fetuses of 2-week pregnant C57BL/6 mice. The livers were minced, repeatedly aspirated through a 23 gauge needle, and passed through nylon wool to remove debris and clumps. ${ }^{11)}$ Cells were suspended in high glucose $(2.5 \mathrm{~g} / \mathrm{ml})$ DMEM (GIBCO) containing 10\% FBS and cultured for $7 \mathrm{~d}$ at $1 \times 10^{5}$ cells per well in 6-well plates, with $3(1 \mu \mathrm{g} / \mathrm{ml})$, interleukin (IL) $-11(50 \mathrm{ng} / \mathrm{ml})$ or TPO $(50 \mathrm{ng} / \mathrm{ml})$, with a change of medium every $3 \mathrm{~d}$. The numbers of megakaryocytes and proplateletes were counted under inverted microscope.

Colony Forming Units in Spleen (CFUs) Assay in Vivo This assay has been described previously. ${ }^{9,12)}$ To examine the effects of 3 on primitive hematopoietic stem cells, 20 C57BL/6 mice were irradiated at 8.5 Gy using a cesium ${ }^{137}$ irradiator, and each mouse was injected in the tail vein with $5 \times 10^{5}$ viable bone marrow stem cells for syngenic bone marrow transplantation (BMT). The mice were divided into four groups of five each. Mice in the control group received PBS, whereas mice in the experimental groups were administered 3, at doses of $0.5,5$ and $50 \mathrm{mg} / \mathrm{kg} / \mathrm{d}$, i.p. or p.o., for $7 \mathrm{~d}$ after syngenic BMT. On day 14 after BMT, all mice were sacrificed, and their spleens were removed, fixed in formalin, stained with hematoxylin and eosin, and examined by light microscopy.

Endotoxin Test An endotoxin assay was performed on each fraction of the chloroform extracts, purified monoacetyldiglycerides from deer antler, and synthetic compounds by the Limulus Amebocyte Lysate (LAL) test, using KTA LAL reagents purchased from Charles River Endosafe, U.S.A., according to the manufacturer's protocol. All materials used were endotoxin free.

\section{RESULTS}

Purification and Structural Determination of Hematopoietic Stem Cell-Stimulating Monoacetyldiglycerides from Cervus nippon Deer Antler During the fractionation of the deer antler extracts and the subsequent chromatographic purification process, each fraction was assayed in vitro for its ability to stimulate the growth of hematopoietic stem cells. The purified bioactive fraction, which had a stimulation index of $1.40 \pm 0.05$, was shown by ${ }^{1} \mathrm{H}-,{ }^{13} \mathrm{C}-$, and 2D-NMR spectroscopy, as well as by FAB-MS and MS-MS, to be a mixture state of monoacetyldiglycerides. ${ }^{6}$ )

Synthesis of Monoacetyldiglycerides We synthesized eight monoacetyldiglycerides, structurally identical to the naturally occurring compounds (Fig. 1). One of these monoacetyldiglycerides, 1-palmitoyl-2-linoleoyl-3-acetylrac-glycerol (3), showed the highest stimulation of hematopoiesis in vitro.

Colony Forming Unit in Culture (CFUc) Assay We found that, using LD cells, synthetic compound $\mathbf{3}$, at concentrations of 0.1 and $1.0 \mu \mathrm{g} / \mathrm{ml}$, had a stimulation index over 1.5 times that of control, when tested in a CFUc assay (Table 


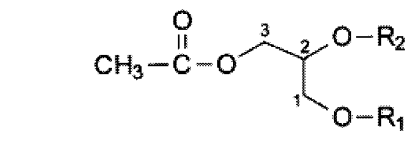

Monoacetyldiglyceride-1 (1): $\mathrm{R}_{\mathrm{l}}=$ oleoyl, $\mathrm{R}_{2}=$ palmitoyl

$$
\begin{aligned}
& -2(2): R_{1}=\text { palmitoyl }, R_{2}=\text { oleoyl } \\
& -3(3): R_{1}=\text { palmitoyl }, R_{2}=\text { linoleoyl } \\
& -4(4): R_{1}=\text { palmitoyl, } R_{2}=\text { linoenoyl } \\
& -5(5): R_{1}=\text { palmitoyl, } R_{2}=\text { arachidonoyl } \\
& -6(6): R_{1}=\text { palmitoyl, } R_{2}=\text { docosahexaenoyl } \\
& -7(7): R_{1}=\text { linoleoyl, } R_{2}=\text { linoleoyl } \\
& -8(8): R_{1}=\text { linoleoyl, } R_{2}=\text { oleoyl }
\end{aligned}
$$

Fig. 1. Structures of Eight Synthetic Monoacetyldiglycerides

Table 1. Stem Cell Stimulation Index of Eight Synthetic Monoacetyldiglycerides in CFUc Assay

\begin{tabular}{lcl}
\hline \hline Monoacetyldiglyceride & $\begin{array}{c}\text { Concentration } \\
(\mu \mathrm{g} / \mathrm{ml})\end{array}$ & Stimulation index \\
\hline Monoacetyldiglyceride-1 (1) & 1.0 & $1.51 \pm 0.05^{* *}$ \\
Monoacetyldiglyceride-2 (2) & 0.1 & $1.38 \pm 0.10^{*}$ \\
& 1.0 & $1.47 \pm 0.13^{*}$ \\
Monoacetyldiglyceride-3 (3) & 0.1 & $1.33 \pm 0.18$ \\
Monoacetyldiglyceride-4 (4) & 1.0 & $1.54 \pm 0.03^{* * *}$ \\
& 0.1 & $1.46 \pm 0.03^{* * *}$ \\
Monoacetyldiglyceride-5 (5) & 1.0 & $1.31 \pm 0.14 *$ \\
& 0.1 & $1.32 \pm 0.12^{*}$ \\
Monoacetyldiglyceride-6 (6) & 1.0 & $1.19 \pm 0.06$ \\
& 0.1 & $1.12 \pm 0.09$ \\
Monoacetyldiglyceride-7 (7) & 1.0 & $1.02 \pm 0.07$ \\
& 0.1 & $1.10 \pm 0.18$ \\
Monoacetyldiglyceride-8 (8) & 1.0 & $1.02 \pm 0.07$ \\
Purified monoacetyldiglycerides & 0.1 & $1.12 \pm 0.12$ \\
from deer antler & 1.0 & $1.24 \pm 0.19$ \\
& 0.1 & $1.40 \pm 0.05$ \\
& 1.0 & \\
& &
\end{tabular}

$* p<0.05, * * p<0.005, * * * p<0.001$ compared with control. Low density (LD) cells were cultured for 1 week with or without the indicated monoacetyldiglyceride, and the number of colonies was counted. Stimulation index $=$ No. of CFUc on sample well/No. of CFUc on control well. Numbers represent the mean \pm S.D. of triplicate wells in at least three independent experiments.

1). When combined with IL-3, 3 stimulation of stem cells was 2.30 times higher than that of control (Table 2).

Lin ${ }^{-} \mathrm{Sca}-1^{+}$cells from mouse bone marrow were used to study the biological activities of purified deer antler monoacetyldiglycerides and compound 3. Purified monoacetyldiglycerides, at concentrations of 0.1 and $1.0 \mu \mathrm{g} / \mathrm{ml}$, stimulated hematopoiesis in the CFUc assay, with stimulation indices of $1.3 \pm 0.07$ and $1.1 \pm 0.10$, respectively. Cells treated with $1.0 \mu \mathrm{g} / \mathrm{ml}$ compound $\mathbf{3}$ produced more and larger

\begin{tabular}{|c|c|c|c|}
\hline Groups & Samples & Colony count ( \pm S.E. $)$ & Stimulation index \\
\hline I & Control & $67.8 \pm 3.2$ & $1.00 \pm 0.04$ \\
\hline II & IL-3 (20 ng/ml) & $124.5 \pm 5.9$ & $1.84 \pm 0.09$ \\
\hline III & $3(0.1 \mu \mathrm{g} / \mathrm{ml})$ & $99.3 \pm 1.8$ & $1.46 \pm 0.03$ \\
\hline IV & $\begin{array}{l}3(0.1 \mu \mathrm{g} / \mathrm{ml}) \\
+\mathrm{IL}-3(20 \mathrm{ng} / \mathrm{ml})\end{array}$ & $156.0 \pm 2.8$ & $2.30 \pm 0.04$ \\
\hline
\end{tabular}
colonies than untreated cells (Fig. 2). Similar results were observed with cells treated with 0.01 and $0.1 \mu \mathrm{g} / \mathrm{ml} \mathrm{com-}$ pound $\mathbf{3}$ (data not shown).

Long Term Culture of $\mathrm{Lin}^{-} \mathrm{Sca}-1^{+}$Cells with Stromal Cells Exposed to 3 The next step was to examine the ef-
Table 2. Stem Cell (LD Cell) Stimulation Index of $\mathbf{3}$ and IL-3
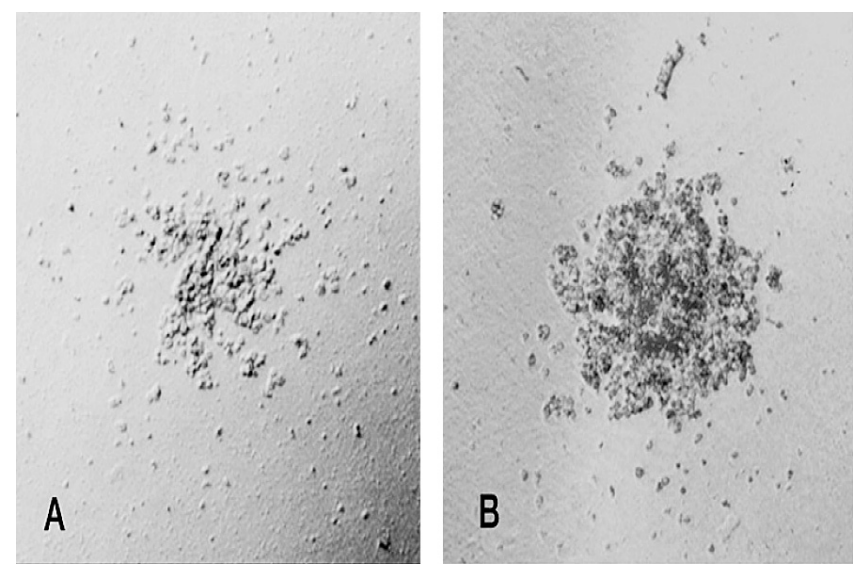

Fig. 2. Effect of $\mathbf{3}$ on CFUc Colony Counts and Sizes

$\mathrm{Lin}^{-} \mathrm{Sca}-1^{+}$cells were cultured for $14 \mathrm{~d}$ in $1.1 \%$ methylcellulose-containing conditioned medium without (A) or with (B) $1 \mu \mathrm{g} / \mathrm{ml}$ compound 3 for $14 \mathrm{~d}$. Cells treated with $\mathbf{3}$ showed more and larger colonies than untreated cells.

fects of $\mathbf{3}$ on primitive hematopoietic stem cells. Lin $^{-} \mathrm{Sca}-1^{+}$ cells were cultured over a bed of irradiated MS-5 cells that had been pre-treated in the presence or absence of compound 3, as described in the Methods section. Lin $^{-} \mathrm{Sca}_{-1}{ }^{+}$cells cultured over MS- 5 cells pre-treated with 3 produced a higher number of cobble stone colonies than $\mathrm{Lin}^{-} \mathrm{Sca}-1^{+}$cells cultured over untreated MS-5 cells (Fig. 3, Table 3).

Expression of SDF-1 mRNA by MS-5 Bone Marrow Stromal Cells MS-5 stromal cells were treated with compound 3 for $24 \mathrm{~h}$ and assayed for expression of mRNA specific to the chemokine SDF-1 by real-time quantitative RTPCR, with GAPDH mRNA expression as an internal control. The SDF-1/GAPDH mRNA ratio in MS-5 cells cultured with 3 was $3.020 \pm 0.025$, compared with $0.0696 \pm 0.034$ in MS-5 cells cultured in the absence of $\mathbf{3}$ (Table 4 ).

Megakaryocyte Culture When we cultured fetal liver stem cells in the presence of $3(1 \mu \mathrm{g} / \mathrm{ml})$, IL-11 $(50 \mathrm{ng} / \mathrm{ml})$ or TPO $(50 \mathrm{ng} / \mathrm{ml})$ for $7 \mathrm{~d}$, and counted the number of megakaryocytes and proplatelets, we found that $\mathbf{3}$ had a stimulation index of $1.69 \pm 0.16$, compared with $2.63 \pm 0.03$ for TPO and $1.43 \pm 0.22$ for IL-11 (Table 5).

Colony Forming Units in Spleen (CFUs) Assay in Vivo In order to determine the in vivo effect of $\mathbf{3}$ on the recovery of hematopoiesis, a CFUs assay was performed in heavily irradiated mice. Mice treated with 3 at a dose of $50 \mathrm{mg} / \mathrm{kg} / \mathrm{d}$ showed a marked increase in splenic nodules and primitive progenitor cells (Fig. 4). Similar results were observed in mice treated with 0.5 and $5.0 \mathrm{mg} / \mathrm{kg} / \mathrm{d} \mathbf{3}$ (data not shown).

Endotoxin Test All the chloroform extracts and purified bioactive monoacetyldiglycerides from deer antler, as well as all synthetic compounds including $\mathbf{3}$, were negative in the en- 

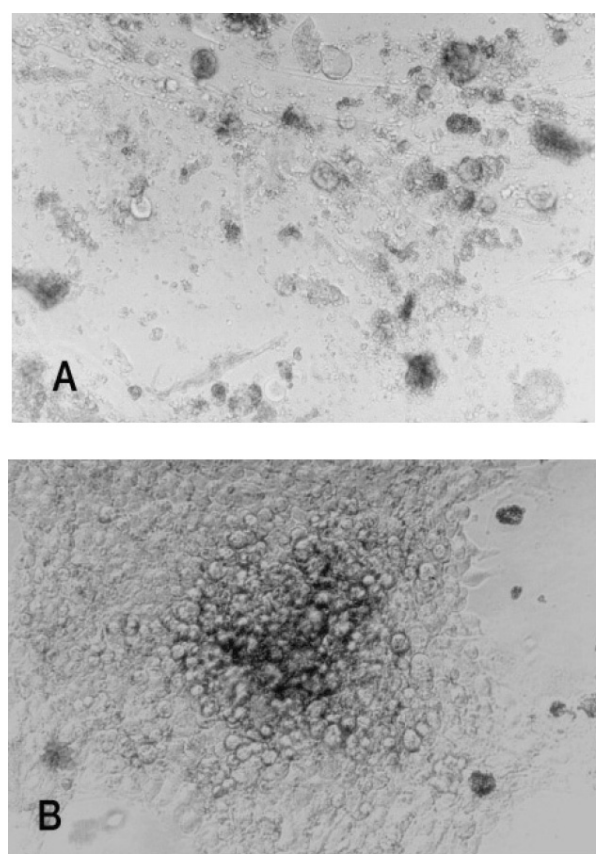

Fig. 3. Cobblestone Colonies of $\mathrm{Lin}^{-} \mathrm{Sca}-1^{+}$Cells Cultured for 6 Weeks with MS-5 Cells (A) or MS-5 Cells Pre-treated with $1 \mu \mathrm{g} / \mathrm{ml} 3$ (B)

MS- 5 cells pre-treated with $\mathbf{3}$ showed more and larger cobble stone colonies than untreated cells.

Table 3. Effects of $\mathbf{3}$ on Proliferation of $\mathrm{Lin}^{-} \mathrm{Sca}-1^{+}$Cells in Long-Term Culture

\begin{tabular}{ccc}
\hline \hline \multicolumn{2}{c}{ Condition $(\mu \mathrm{g} / \mathrm{ml})$} & No. of cobblestone colonies per flask \\
\hline Control & & $1.2 \pm 0.12$ \\
$\mathbf{3}$ & 0.01 & $5.0 \pm 0.21^{*}$ \\
& 0.1 & $5.7 \pm 0.24^{*}$ \\
& 1.0 & $10.4 \pm 0.25^{*}$ \\
\hline
\end{tabular}

$* p<0.05$. MS- 5 were pre-incubated in the presence or absence of $\mathbf{3}$ for $1 \mathrm{~d}$ and washed twice. Sca-1 positive cells were cultured for 6 weeks on MS- 5 cells treated in the presence or absence of $\mathbf{3}$, and the number of cobblestone colonies per flask was counted.

Table 4. Effect of 3 on the SDF-1 mRNA Level of MS-5 Cells

\begin{tabular}{clll}
\hline \hline Group & \multicolumn{1}{c}{ SDF-1 } & \multicolumn{1}{c}{ GAPDH } & SDF-1/GAPDH \\
\hline Control & $0.0108 \pm 0.0007$ & $0.0155 \pm 0.0005$ & $0.696 \pm 0.034$ \\
$\mathbf{3}$ & $0.0209 \pm 0.0002^{*}$ & $0.0069 \pm 0.0008^{*}$ & $3.020 \pm 0.025^{*}$
\end{tabular}

$* p<0.05$ compared with control. The detector curves of GAPDH and SDF-1 showed a satisfactory slope curve: $\mathrm{R}_{2}$ of SDF-1, 0.998514; $\mathrm{R}_{2}$ of GAPDH, 0.997763. Data reported are the means \pm S.D. of triplicate reactions.

Table 5. Stimulation Index of $\mathbf{3}$ in Megakaryocyte (Pro-platelet) Proliferation Assay

\begin{tabular}{cl}
\hline \hline Condition & Stimulation index \\
\hline TPO $(50 \mathrm{ng} / \mathrm{ml})$ & $2.63 \pm 0.03^{*}$ \\
$\mathrm{IL}-11(50 \mathrm{ng} / \mathrm{ml})$ & $1.43 \pm 0.22$ \\
$\mathbf{3}(1 \mu \mathrm{g} / \mathrm{ml})$ & $1.69 \pm 0.16^{*}$
\end{tabular}

$* p<0.005$. Stimulation index $=$ No. of megakaryocytes on sample well/No. of megakaryocytes on control well. All tests were repeated more than three times, each in triplicate.
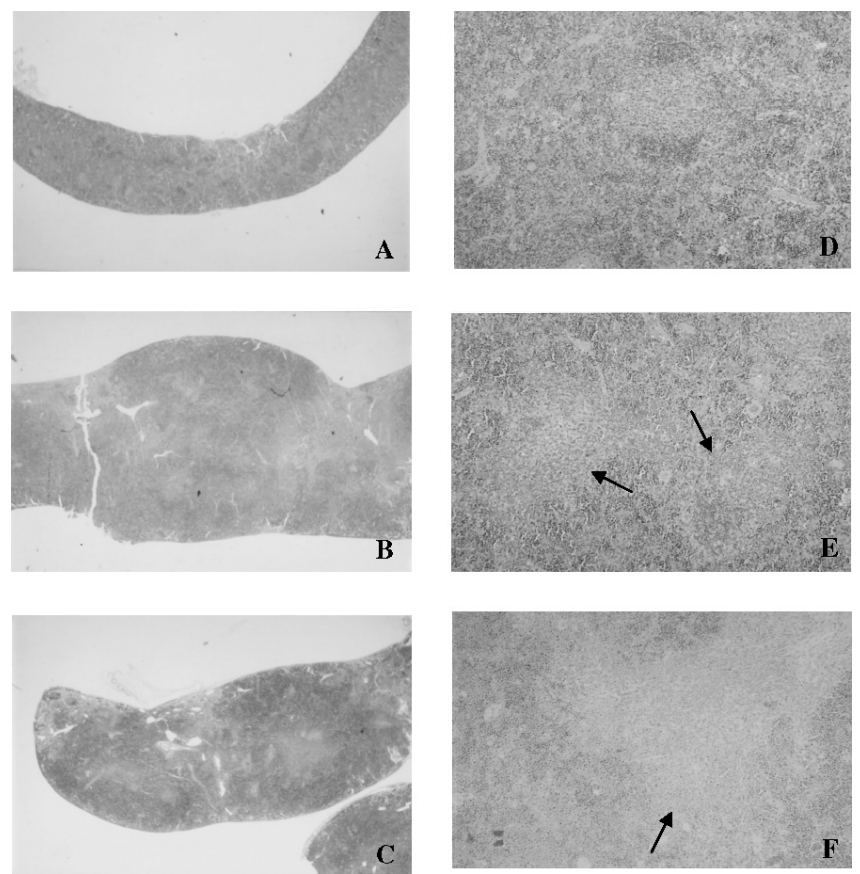

Fig. 4. Microscopic Examination of Spleens from Mice Treated with 3

(A, D) Control mice; (B, E) Mice treated with 3 (50 mg/kg/d i.p.); (C, F) Mice treated with $3(50 \mathrm{mg} / \mathrm{kg} / \mathrm{d}$ p.o. $)$. (E, F) Higher magnification of micrographic section of mice treated with $\mathbf{3}$, the arrowhead indicates an increase in splenic nodules comprised of progenitor cells. Treatment with 3 i.p or p.o. (B, C, E, F) markedly increased the number of splenic nodules and the numbers of primitive progenitor cells and megakaryocytes.

dotoxin test (data not shown).

\section{DISCUSSION}

We previously showed that monoacetyldiglycerides isolated from deer antler, Cervus nippon, were potent stimulants of hematopoiesis in vitro. We demonstrated that these active compounds were monoacetyldiglycerides by mass, NMR and IR spectrometry. ${ }^{6}$ In addition, six monoacetyldiglycerides compounds were synthesized, ${ }^{7)}$ of which one, compound $\mathbf{3}$, showed hematopoietic stimulatory activity. ${ }^{6}$ In the present study, we synthesized 8 monoacetyldiglycerides and assayed their effects on hematopoietic stem cell stimulation in vitro and in vivo, in order to determine their mechanism of action. One of these synthetic compounds, 1-palmitoyl-2-linoleoyl3-acetyl-rac-glycerol (3), which was structurally identical to one of the naturally occurring monoacetyldiglycerides, showed the most potent stimulation effect of hematopoiesis in vitro. We therefore assayed the stimulatory effects of $\mathbf{3}$ on hematopoietic stem cells and bone marrow stromal cells, both in vitro and in vivo.

The results of the CFUc assay showed that compound $\mathbf{3}$ stimulated the proliferation of bone marrow stem cells under both culture conditions, i.e., in the presence or absence of IL3 , with the combination with IL-3 showing the highest BM stimulatory activity.

We used the CFUs assay to evaluate the biological activities of naturally occurring and synthetic monoacetyldiglycerides on primitive stem cells in vivo. In heavily irradiated mice, splenic colonies eight days after BMT were shown by CFUs assays to be comprised of multiple differentiated com- 
mitted cells, whereas, on day 14, colonies were comprised of undifferentiated pluripotent stem cells..$^{9,13,14)}$ We therefore tested the effect of $\mathbf{3}$ on late-forming, $14 \mathrm{~d}$ cultures. We found that this compound, administered orally or intraperitoneally (not shown), accelerated the recovery of hematopoietic stem cells from injuries induced by sublethal doses of whole body radiation and/or mitomycin $\mathrm{C}$ (unpublished data).

We also studied the effect of $\mathbf{3}$ on long-term bone marrow culture. Lin $^{-} \mathrm{Sca}-1^{+}$cells co-cultured over bone marrow stromal cell beds previously exposed to 3 had a 5-10 fold increase in hematopoiesis. Cobblestone area-forming cells represent primitive progenitors as well as hematopoietic stem cells. ${ }^{9)}$ Compound $\mathbf{3}$ induced an increase in the number of cobblestone cell colonies, indicating that this compound enhanced proliferation of primitive $\mathrm{Lin}^{-} \mathrm{Sca}-1^{+}$cells, as well as the stimulation of megakaryocyte progenitor cells. Stromal cell derived factor 1 (SDF-1) stimulates the expansion and maturation of myeloid progenitors in the bone marrow, regulates the migration of leukocytes from blood to tissues, and is involved in the trafficking and homing of lymphocytes. Mice lacking the SDF-1 gene die perinatally, as well as presenting with multiple defects of development, including a severe reduction of $\mathrm{B}$ cell and myeloid progenitors in bone marrow. ${ }^{17,18)}$ MS-5 cells pretreated with 3 expressed 4.3-fold higher SDF-1 mRNA than did cells pretreated in the absence of 3 (Table 6). The increase in SDF-1 mRNA induced by 3 suggests that this chemokine may act in synergy with other cytokines to promote myeloid, erythroid and megakaryocyte proliferation. ${ }^{15)}$ Taken together, these findings suggest that $\mathbf{3}$ acts directly on stem cells as well as on stromal cells.

Although the mechanism of action of $\mathbf{3}$ on hematopoietic and stromal cells is not yet fully elucidated, this compound most likely acts by inducing progenitor cell stimulation and secretion of IL-3 and GM-CSF. Cytokines secreted by cells in response to $\mathbf{3}$ may stimulate the growth and differentiation of bone marrow stem cells, as well as stimulating stromal cell function. Compound $\mathbf{3}$ and other monoacetyldiglycerides may act at the transcriptional level, in a way similar to that of diacylglycerol (DAG), which may activate the enzyme PKC, subsequently activating various transcription factors. ${ }^{16)}$

In summary, our results indicate that monoacetyldiglycerides, a previously undescribed class of compounds, are po- tent stimulators of hematopoiesis. These monoacetyldiglycerides hold considerable promise for future clinical use.

Acknowledgments We thank Professor Ikehara and Dr. Hisha for reviewing our in vivo tissue culture results. This work was supported by the KOSEF (R14-2002-015-01002-0, R04-2003-000-10085-0 and R03-2001-000-00028-0) and the MHW (01-PJ11-PG9-01NT00-0044 and HMP-96-D-1011). SHC, JYY and MGK are recipients of graduate fellowships from the Brain Korea 21 program.

\section{REFERENCES}

1) Kim J. G., "Illustrated Natural Drugs Encyclopedia (color edition)," Vol. 2, Namsandang Publishing Co., Seoul, 1989, pp. 332-333.

2) Namba T., "The Encyclopedia of Wan-Yaku (Traditional Sino-Japanese Medicine) with Color Pictures," Vol. I, Hoikusha Publishing Co., Osaka, 1980, pp. 281-285.

3) Liu X. L., Chungitsa Chin., 25, 759-760 (1984).

4) Kim S.-H., Kim M. J., Korean J. BRM, 1, 23-30 (1993).

5) Kim M. J., Yum N., Choi M., Kim S.-H., Korean J. BRM, 4, 47-55 (1994).

6) Yang H. O., Kim S.-H., Cho S.-H., Kim M.-G., Seo J. Y., Park J. S., Jhon G.-J., Han S.-Y., Chem. Pharm. Bull., 52, 874-878 (2004).

7) Kim Y. H., Han S.-Y., Cho S.-H., Yoo J. S., Jhon G.-J., Rapid Comm. Mass Spec., 13, 481-487 (1999).

8) Itoh K., Tezuka H., Sakoda H., Konno M., Nagata K., Uchiyama T., Uchino H., Mori K. J., Exp. Hematol, 17, 145-153 (1989).

9) Hisha H., Yamada H., Sakurai M. H., Kiyohara H., Li Y., Yu C., Takemoto N., Kawamura H., Yamaura K., Shinohara S., Komatsu Y., Aburada M., Ikehara S., Blood, 90, 1022-1030 (1997).

10) Visser J. W. M., Bauman J. G. J., Mulder A. H., Eliason J. F., De Leeuw A. M., J. Exp. Med., 159, 1576-1590 (1984).

11) Lecine P., Villeval J.-L., Vyas P., Swencki B., Xu Y., Shivdasani R. A., Blood, 92, 1608-1616 (1998).

12) Till J. E., McCulloch E. A., Radiation Res., 14, 213-222 (1961).

13) Spangrude G. J., Heimfeld S., Weissman I. L., Science, 241, 58-62 (1988).

14) Spangrude G. J., Smith L., Uchida N., Ikuta K., Heimfeld S., Friedman J., Weissman I. L., Blood, 78, 1395-1402 (1991).

15) Sanz-Rodriguez F., Hidalgo A., Teixido J., Blood, 97, 346-351 (2001).

16) Abbas A. K., Lichtman A. H., Pober J. S., "Cellular and Molecular Immunology," 4th ed., W.B. Saunders Company, Philadelphia, 2000, pp. $248-269$.

17) Baggioloni M., Dewald B., Moser B., Annu. Rev. Immunol., 15, 675705 (1997)

18) Baggiolini M., Nature (London), 392, 565-568 (1998). 